\title{
Elastic Space in the Interior of Indonesia's Traditional Settlement
}

\author{
Lintu Tulistyantoro ${ }^{1}$, Purnama Esa Dora Tedjokoesoemo ${ }^{2}$, Yusita Kusumarini ${ }^{3}$ \\ $1,2 \& 3$ Faculty of Art and Design Petra Christian University, Indonesia \\ 11intut@petra.ac.id, ${ }^{2}$ esa@petra.ac.id, ${ }^{3}$ yusita@petra.ac.id
}

\begin{abstract}
Elastic is an adjective that refers to something that can expand and shrink. This word expresses a dynamic and unrigid situation. In consideration of this definition, the phrase "elastic space" can be understood as a space that is expandable temporarily and can be shrunk after a period of time. People in traditional community in Indonesia, has known this nature of space since old times. This type of space is very distinct one to another and very much determined by the context of where the space is located. The case of Tengger and Osing traditional settlements are very interesting to be explored visually as well as their background process to form the elastic space. Both objects are located in the same climate but vary in understanding of character and visualizing of the elastic space. This paper will discuss the decisive elements that formed the character of space. The discussion is limited to the understanding of space containing function, shelter, humans, and their activity in understanding of Indonesia's traditional settlement. This research is conducted in qualitative method with ethnographic and participation approach. Data mining was conducted by direct on field exploration and observation from elastic space found in Tengger and Osing community.
\end{abstract}

Keywords: elastic space, tengger, osing, nusantara

\section{INTRODUCTION}

\subsection{Understanding the term "elastic space"}

The word "elastic" is defined as an object that is able to resume its normal shape spontaneously after contraction, dilatation, or distortion. It is a state that allows a thing to expand and shrink to its initial size or form. Elasticity of a material or object is temporary as the object or material can be pushed to expand and be pulled back to its original position. The driving force to expand and the pull back to its original state is the main element and very important in determining the elasticity.

Elastic space is not a common term used to describe the nature of space, especially in the interior. This term surprisingly fit to be used to describe one character or nature of space that occurs in the traditional space of a community in the archipelago. Space in the interior understanding is defined as a physical rigid limitation to form a room [1]. As interior is part of space, it too has limitations and have certain functions and specific meaning to support human activity. Hereinafter this space limitation will be called as shelter. Interior is an area that sheltered by floor, walls, and ceiling [2]. This definition is based on contextual idea from four 
seasoned area. Interior in archipelago has different view as it fits to contextual location. Tropical climate which has insignificant temperature difference suggest different approach for sheltering.

By this common space definition and its rigidity suggested by Pile, elastic space in the archipelago become interesting to be further researched as it offers the contrary. This paper will focus on the driving force to expand and to pull back to its original state found in traditional space of a community in the archipelago, in focus of traditional community in Tengger and Osing.

\section{METHOD}

This research was conducted in qualitative method with ethnography and participatory approach [3]. Ethnographic approach is a method to feel and experience the elasticity of space together with and in the society [4]. This approach is used in aim to get the spatial experience. This approach is essential to understand the elastic space in the interior of the research object. Spatial experience is best explored by being part of the community and to do daily activities together. This approach enables the researcher to directly interact with the community without distance and documenting the onsite data. Activities that are particularly emphasized are those directly related to ceremonial activities, which have high possibilities to create elastic space. Participatory approach is conducted to build a sense of togetherness and play a role in the process of space experience. Both techniques are conducted to explore the onsite data in objective to achieve accurate space experience.

Analytical process was conducted in triangulation method. Data gathered were classified by pairing and comparing them with personal experience and opinion from community figure or another source. The expected conclusion is a classified statement so that an optimal accuracy is achieved.

\section{RESULT AND DISCUSSION}

The theory that is developing at this time confirms that interior is an area that is sheltered by floor, walls, and ceiling [2]. Interior is also defined by Serres as a real container of limited human life experience [5][6]. Interior in archipelago has different views as it fits to contextual location. Tropical climate which has insignificant temperature difference suggest different approach for sheltering. Prijotomo [in 7], mentioned that the architecture of the archipelago is a shelter architecture. It is a space to mere shelter from the sun or from the rain. The main essence of architecture in the archipelago offers an unrigid interior in contrary of common western definition of space. Physical shelter is not an essential element to present a space in traditional interior. Physical shelter is nonrigid, can be created and perish at an uncertain time, even when the shelter is able to last for a very long period. On the other hand, nonphysical shelter is more essential to shape an interior because nonphysical element serves a very severe consequence. Nonphysical shelter such as personal and communal norm, each of these norms has severe sanctions physically, morally, and ethically. For example, violations of the norm can end in murder [8].

In traditional Javanese community, residential space is called omah, which can be broken down into words "om" and "mah". Om has the meaning of sky or man. Mah owns the earth or woman. Both are united into omah that means uniting heaven and earth or male and female. So that in Javanese tradition, a house is a harmonisation of male and female [9]. The two cases below will discuss house/ residential space based on the omah thought. 


\subsection{The Tengger Space Structure}

Cosmologically the spiritual structure of the people in Tengger is centered on the main pedanyangan, the Bromo Mountain [10]. Every village has their own pedayangan or village temple as the spiritual center of the community. Individually, the Tengger has sacred place in the house for ancestral places that have passed away. This sacred place located in one place and can be a small table or room. Especially for the village head, they have a special pedanyangan that specifically functions for the spiritual legality which is a place for the village danyang. This special pedanyangan contains symbols of the presence of spirits such as white cloth and others.
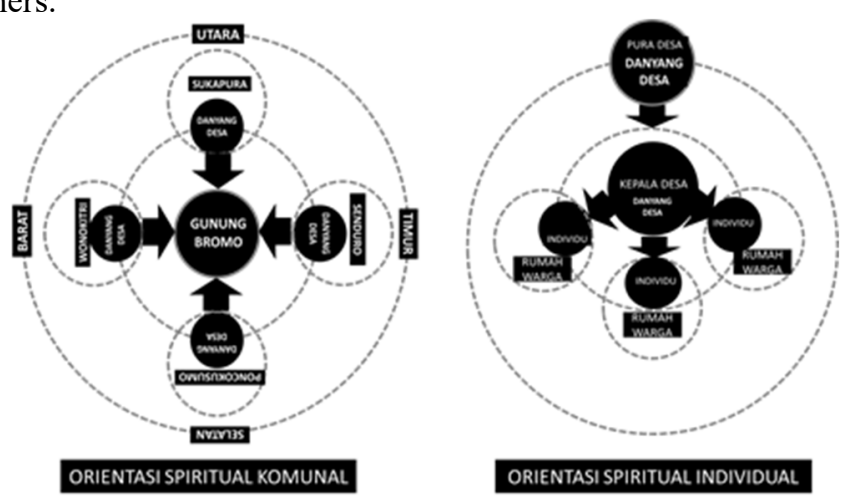

Picture 01. The macro spiritual structure of the Tengger people, centered on Bromo Mountain. Likewise, the orientation of the ritual that is carried out always leads to Mount Bromo.

So, in spiritual space structure, space hierarchy clearly start from individual, head of village, village temple, and Bromo Mountain. In addition to these places there are also special places such as springs, bridges, and some special places that they believe are special for ancestral spirits.

\subsubsection{The Interior of The Tengger Community}

The Tengger community's settlement spaces generally form a row of houses that line up and face the Bromo Mountain [11]. Although, nowadays many houses are no longer oriented parallel, but rather emphasize the orientation of the highway. The dwelling of each family consists of pedayoan, gedong, pawon, pedaringan, and pedanyangan.

Pedayoan is a living room that is used to receive guests from outside of the community or not a Tengger people. Pedayoan also serves as a place to conduct large ceremonies such as weddings and so on that involve many people and public event by nature.

Gedong is a bedroom for parents. It is a special room that always exist in a dwelling place in addition to other rooms.

Pedaringan is a special space to store staples for family food supplies such as rice, oil, and other food supplies. then the kitchen is part of the house which is a women's room and as a center for women's activities to prepare the family meals. Pedaringan is a special place, because pedaringan has a special spell for a large ceremony to conduct. Spiritual authority 
rests with the village head's wife. The village head's wife is the owner of the spell for pedaringan. The pedaringan is a women's room. This mantra is passed down from generation to generation.

Pawon is the center of daily activities for women in Tengger. Every house has a pawon. The size of pawon is determined by the activity of the homeowner. Tengger community has a characteristic in their pawon that is the presence of more than one fireplace. The Tengger fireplace located in the pawon and the fireplace elsewhere. Pawon has several fireplaces consisting of main and additional fireplaces. The main fireplace is a fireplace specifically used for cooking rice. Special treatment occurs at this place, namely the presence of spells and offerings. Fireplaces in other places has main function as gegenen or temporary heater and function as well to become the table and laying offerings during the ceremony. Family ceremonies are also held at this place.

The entire ritual in the entire life of the Tengger community is led by a shaman. Each village has its own shaman as the highest spiritual leader. Likewise, for village ritual matters up to the individual, the role of the shaman is very important. Interior space can be understood as a multilevel space between individuals, villages, and Tengger in general (see picture 01, Individual Spiritual Orientation).

The interior of the residential space in Tengger has a special character, because the core space in the residence is a gedong. The space resembles the beginning and the center of life, the husband and wife room. The Tengger community housing always has access from the front, right, and left side. However, only two are active, the front and one from the side, while the other side is only used for special purposes.

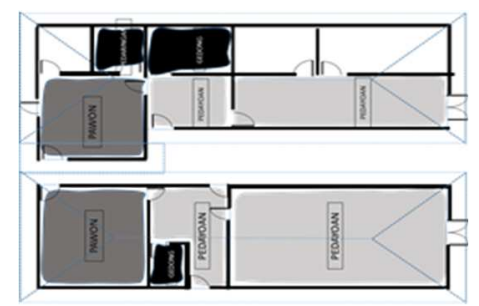

Picture 02. The elastic zones for men and women that can develop according to human activities.

Theoretically the expansion of space can occur due to several things such as communal activities that require sufficient space. Rituals of marriage, death, and so on are examples that require the space to expand. The expansion of space happens very naturally like the flow of liquid or gas flowing anywhere that it allows to flow. Expansion of space occurs in an elastic way, meaning that after the ceremonial, the space will return to the initial position and state. The development of space with this elastic nature occurs as a result of a capacity demand due to a communal ceremonial.

The elasticity of space occurs with unlimited possibilities and limitless until the need for function is fulfilled. The direction of spatial development follows the access to dwellings that have been prepared in the planning. This access is not open every day, but in certain events the access is automatically opened to accommodate the human capacity. This incident occurred because of the rigid community building so that the expansion of space can only occur through access to the existing housing on the right and left of the residence. 


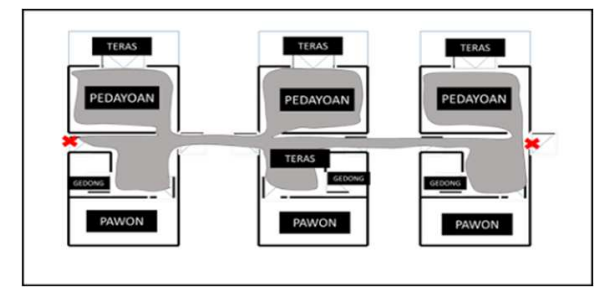

Picture 03. An illustration of elastic space in the Tengger community. $\mathrm{X}$ is an area that is closed when not needed. The space will expand because of the urgency of space due to human needs and increased activity.

The elastic process is formed due to human capacity and activities to make available space. This can be seen as human activity increases while space does not move. This elasticity comes as a result of similarity in spiritual matters. Spatial development is done by making room expansion so that the initially small living room becomes larger. As well as in the pawon part. One room that do not experience expansion is gedong because gedong is not necessary to enlarge when the ritual occurs.

\subsection{The Osing Space Structure}

Osing community is a special community that has differences compared with other communities in the archipelago [12]. In spiritual structure, the Osing community is very much bound to ancestral power. Ancestors who are considered influential in the life of the Osing community in general are the great-grandfather of Cili. The spiritual center of the Osing community in Kemiren village is the punden buyut cili. This is seen in every ritual, both individually and communally. All rituals always begin in this place. Individual spiritual center in each family is in the house.

\subsubsection{The Interior of The Osing Community}

The space in the Osing community settlement is divided into 3 areas, namely bale, jrumyah, and pawon. Bale is an area that is used to accept men and outsiders. Access to this place is through the main door, while the other part of the house is a very private and has bed equipment with poles at the four ends and it is called plonco pegawangan. Jrumyah is space located in the middle of the Osing community settlement. This space is the most enclosed and sacred. This space is specifically inhabited by nuclear families, male and female. In this area there is a place of rice as a symbol of life that has been spelled specifically for its users. This place is always treated specially.

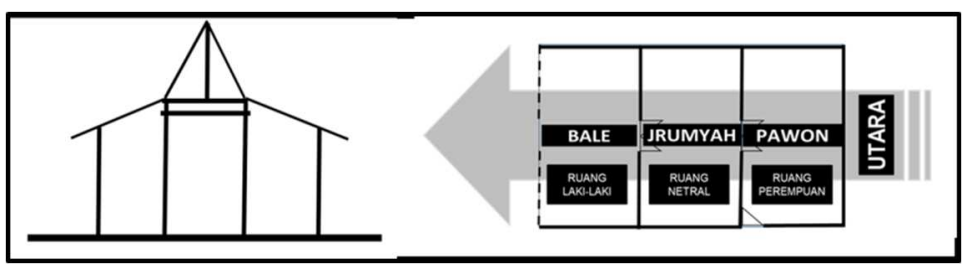


Picture 04. Osing type of house with the division of space consisting of male, neutral, and female rooms.

The space of women and men is an elastic space according to human needs and activities

In every special ritual, Jrumyah serve as the main place to perform the ritual. Marriage ceremonial is always beginning with presenting ancestors through rituals held in an open room. This activity was attended by men only, both Osing people and outsiders who are invited. Osing community traditional settlement has developed with levelings ranging from one, two, three and so on. What they have never left is to make offerings collectively for offerings to the ancestors.

Spatial expansion occurs by dismantling the surrounding walls. Space expanding by removing temporary spaces. Space divider system is not physical and not permanent. Such patterns can be traced through the structure system and the use of its construction. It means in every ceremonial that attended by a lot of people the space can expand easily to the right, left, and front. The kitchen also has the same function. This space belongs to women and only women have areas that correspond to certain boundaries.

The elasticity of the space forms a knock-down structural system so that the walls are not massive, the walls are very flexible. The size of the wall follows the modules that have been determined so that they do not obstruct a temporary change in the space itself. Lightweight material allows changes at any time to achieve changes in the shrinkage or extension. The elastic spaces are the space of men (bale) and women (pawon). Bale is urged to be elastic by the activities to receive guests, while the pawon is urged by cooking activities in large numbers. The elasticity of space can develop linearly due to the nature of space itself. In addition, the expansion of space is not limited by circumstances.

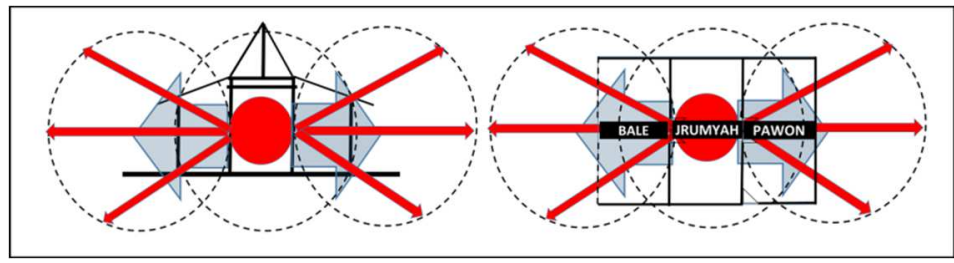

Picture 05 . The process of elastic space can occur due to the encouragement of human interests and activities that require space to develop at a certain time and return to its original form.

\section{CONCLUSION}

Elastic space emphasizes the basic elements of space in humans and their activities. Two types of elastic space in traditional settlement of Tengger and Osing community covers the development of space through floating and shelter shrinkage. This process occurs as a result of a force that occurs caused by the space requirements. First model requires interior development system that is flexible with knock down system. Spatial development occurs by dismantling bamboo or wood walls, that will be returned to normal initial condition when the event has done. Second model, on the other hand, shows elastic space that occurs through preset access and exit. This access is prepared on the right and left side of the house, so that anytime needed, space expansion can be easily done through this access connection. Elastic space in the second model is an adaptation caused by different ambient temperature. The main factor that drives this elastic space to happen are humans and their activities which demand more user capacity than before. 


\section{ACKNOWLEDGEMENT}

This paper is happened by the support of PDUPT according to contract No. 7/E/KPT/2019 dated on February 19th 2019 and 113/SP2H/LT/DRPM/2019 dated on March 11th, 2019 in the period of 2017-2019, Tengger's high priest Tomo whom overseas Tengger community in Probolinggo, Lumajang, Malang, and Pasuruan as interviewees for made way for this research to happen, Ngadas village head, Sukapura Probolinggo, Mulyono villagers of Ngadisari and the owner of Ngadisari homestay, Sukapura Probolinggo, Muhaimin traditional leader of Osing community, Banyuwangi, Eko interviewee and owner of homestay for lots of information, Aekanu Haryono cultural practitioner of Banyuwangi.

\section{REFERENCES}

[1]. Ching, DK. Architecture Form, Space, and Order fourth edition. New Jersey: John Wiley and Son, 2014

[2]. John F. Pile. "Interior Design", New Jersey: Pearson, 2003

[3]. Groat, L., \& Wang, D. (2002). Architecture Research Method. Canada: John Wiley and Son.

[4]. Bearfield, Domonic A., Evan M Berman, Melvin J. Dubnick. Encyclopedia of Public Administration and Public Policy, Chapter: Ethnographic Research third edition. Publisher: Taylor and Francis, 2015

[5]. Ayuninggar, Dianing Primanita, Antariksa Antariksa, Dian Kusuma Wardhani, "The Dwelling Pattern of Tengger Community at Wonokitri Village of Pasuruan Distrik" Tesa Arsitektur, Journal of Architectural Discourses, Vol. 10 No.1 p.28-41.

[6]. Michel Serres, The Five Sense: Boxes," in the Five Senes: A Philosophy of Mingled Bodies, trans. Margaret Sankey and Peter Cowley (London Continuum, 2008)

[7]. Fadli, Moh. Constitutional Recognition and Legal Protection for Local Religion in Indonesia: A Discourse on Local Religion of the Tengger and Baduy People. Pertanika Journal of Social Science and Humanity, Vol 25, No. 2, pp 601-614, 2017.

[8]. Tulistyantoro, Lintu. Interior Menurut Pandangan Masyarakat Madura. Dissertation, Institut Teknologi Sepuluh Nopember, 2016.

[9]. Musman, Asti. Filosofi Rumah Jawa. Yogyakarta: Pustaka Jawi. 2017

[10]. Subadyo, A. Tutut "Arsitektur Pekarangan Suku Tengger di Kantung Taman Nasional Bromo Tengger Semeru” Prosiding Temu Ilmiah IPLBI 2016, p. 31-40

[11]. Suyono. Mistisisme Tengger. Bantul: LKiS Printing Cemerlang. 2009.

[12]. Taufik, Firmanto. Suku Osing, Perspektif Etnografi, Sosial, Hukum Dan Budaya. Malang: Intelegensia. 2019. 